\title{
Early Childhood Education Papers
}

https://journal.unnes.ac.id/sju/index.php/belia

\section{Weight and Height Growth of Children Age 14-23 Months Reviewed from Nutrition Intake}

\author{
Nelatul Izzah ${ }^{\bowtie}$, Sri Sularti Dewanti Handayani \\ DOI: http://dx.doi.org/10.15294/belia.v9i1.32619
}

Department of Early Childhood Teacher Education, Universitas Negeri Semarang, Indonesia

\section{History Article}

Submitted 19 April 2020

Revised 13 May 2020

Accepted 4 June 2020

\section{Keywords}

Breast Milk; Growth; Height; Infant Formula; Weight

\begin{abstract}
Breast milk is the best food for babies. WHO recommends exclusive breastfeeding during the first 6 months of birth in infants. Breast milk contains all the substances that babies need. However, there are still babies who are not given exclusive breastfeeding and have never even felt breast milk. This is due to the mother's breastmilk not coming out, working mothers, or the production of breastmilk that is felt to be inadequate in meeting the needs of the baby. This study discusses the differences in growth focused on the weight and height of children aged 14-23 months who drink breast milk and infant formula. This type of research is a comparative study with cross sectional design. The population is 115 children aged 12-24 months in Sekaran village. As in this study, respondents are 30 mothers who have children aged 14-23 months. While the sample is 15 children who drink breast milk and 15 children who drink infant formula. The sampling technique uses purposive sampling, where the sample is selected according to predetermined inclusion criteria. Data collection is done through questionnaires, interviews, and documentation. Growth data is seen through KMS (health card), filling questionnaires, and interviews with respondents. Hypothesis testing uses an independent $t$ test. The results showed that there are differences in body weight and height growth between children aged 14-23 months who are breastfeed and who take infant formula. The average weight growth value of children who drink breast milk is 10.94 and children who drink formula milk 11.83. The average height growth value of children who drink breast milk is 81.85 and children who drink formula milk 78.46. The difference in average body weight of children who drink breast milk with children who drink formula milk is 1.43. While the difference in the average height of a child who drinks milk with a child who drinks formula milk is 3.39 .
\end{abstract}

\section{How to Cite}

Izzah, I., \& Handayani, S. S. D. (2020). Weight and Height Growth of Children Age 14-23 Months Reviewed from Nutrition Intake. Early Childhood Education Papers, 9(1), 49-54. 


\section{INTRODUCTION}

Growth is a process of increasing size in living things. It is real, can be measured, and can be observed. Growth includes body length, weight, head circumference, arm circumference, and others. Growth has an impact on physical aspects that can be measured by means (Estuti, 2014). Children under the age of three will experience rapid growth commonly known as the golden age. Therefore, parents must pay attention to nutrition intake in children. According to Putri (2012) many parents assume that children can grow by themselves. Rastiti (2013) explains that the age of the first two years of life is a vulnerable period with various nutritional problems.

Parents are the first environment associated with children (Ayuningtyas, 2013). Parental skills are needed in stimulating early childhood so that children can grow optimally and through stages of development according to their age (Waluyo et al, 2018). At the age of golden age, children need to get a lot of stimulation for growth and development. Stimulation is done so that children can experience growth optimally. There are several factors that affect a child's growth, one of them is breastfeeding during infancy. This is in line with the opinion of Conita (2014) that babies aged 0-6 months can grow and develop optimally only by drinking breast milk which is the best food for babies.

Growth and development of children is influenced by exclusive breastfeeding in the first 6 months of birth. That is because breast milk is the most perfect nutrient for babies and contains antibodies so that children are rarely sick and do not experience weight loss (Sara, 2018). Parents need to know the importance of breastfeeding for infants. That is because breast milk can affect the growth of children. Breastfeeding children until the age of 2 years are important for children's growth. This is in line with Dahliansyah (2018) who argues that the 6-24 month period is the most important time for children's growth. Malnutrition in this period is caused by children having high nutritional needs in the growth process. However, the quantity and quality of food provided to children is not sufficient for nutritional needs, especially when finished exclusive breastfeeding. Child growth is closely related to the intake of nutrients consumed as babies. Parents who know the benefits of breast milk will give breast milk to children up to 2 years of age.

Breast milk is a substance that is needed for infants under the age of 2 years, especially aged 0-6 months. Giving breast milk in the first
6 months of birth is very important. That is because breast milk contains many vitamins and nutritious substances that are useful for children's growth and development. This is in line with Danang (2015) who believes that breast milk is the best and most perfect first food for babies. High nutritional content and the presence of immune substances in it, making breast milk is not replaced by infant formula is great and expensive though. This is because the nutrients contained in breast milk are good for growing children. Good weaning is recommended until the child is 2 years old (Himawan, 2006).

Children aged 0-6 years are ages where it is very important for parents to pay attention to children's health, growth and development (Febriana et al., 2018). The phenomenon that occurs in the community is that children aged 6-24 months no longer drink breast milk. There are also some toddlers who have never tasted milk from birth. Parents give formula milk as a substitute for breast milk. This is done because breast milk does not come out, children do not want to drink breast milk, mothers must work out of town, and other factors. Therefore, parents provide infant formula milk to meet the nutritional needs of their children. Whereas children who have experienced breast milk, when the child is more than 6 months old, the child does not drink breast milk anymore. There is even a 2-month-old child who has been introduced to complementary food for breast milk and given infant formula. This certainly can affect the quality of children's growth.

The results of a preliminary study conducted by the researcher at RW 5 Sekaran Village on 7 mothers who have children aged 12-24 months; there are 2 mothers do not breastfeed their children from birth and 5 mothers gave breastfeeding to their children up to 12 months of age. The reason mothers don't breastfeed is because they have to work until the afternoon. While children who get breast milk, some of them have also been introduced to additional food since the age of 3 months and also given infant formula as an additional nutrient for children.

The researcher also conducts interviews with one village midwife and Posyandu (Integrated Service Post) cadre. The village's midwife explains that it is related to the scope of breastfeeding and the condition of the growth of toddlers in Sekaran Village. The results of interviews obtained from village's midwife are toddlers in Sekaran Village, are still experiencing growth problems, this can be seen from the weighing results reported by Posyandu cadres. The village midwife 
says that the IMD (Early Breastfeeding Initiation) in Sekaran Village had not reached $100 \%$. The scope of exclusive breastfeeding in Sekaran Village has not met the target, in this case still found mothers who do not breastfeed their children for certain reasons. Even though the Puskesmas has promoted exclusive breastfeeding and the importance of monitoring growth, there are still parents who do not understand the importance of exclusive breastfeeding and regular weighing. This can be seen from formula feeding too early which is caused by the lack of parental knowledge about breast milk.

Posyandu cadres said that the there is children who experience growth retardation in weighing in 2018 and 2019; such as body weight did not increase, overweight, and weight are under the red line curve. Parents are less attentive in monitoring the child's growth. This can be seen from the number of children who routinely weigh only a little. According to Posyandu cadres, there are many parents come to take their children to weigh if there are vitamins yet parents are less enthusiastic if there is no provision of certain vitamins. Growth disturbance is closely related to the pattern of feeding children. Nutrition is an important factor that plays a role in the process of growing children.

The purpose of this research is to find out the difference in body weight and height growth of children who drink breast milk as infants up to the age of 2 years and children who have never taken breast milk since infancy (drinking infant formula) in Sekaran Village, Gunungpati District of Semarang City. Therefore, various activities in this research are directed to find answers to the problems that have been stated above. The advantage of this research is seeing how the growth of children with different nutritional intake (breast milk and formula milk). The number of research on breastfeeding and growth of under two years old childreen is still little. So, it is expected that this research can provide more knowledge to parents and the community about the importance of breastfeeding during the first six months of birth and continued until the age of two years.

\section{METHOD}

This research is a comparative quantitative research using cross sectional design. According to Nursalam (2003), cross sectional research is a type of research that emphasizes the measurement time of dependent and independent variables that is only once. Dependent and independent variables are assessed at the same time and there was no follow-up. The purpose of this comparative study is to identify differences in body weight and height growth in children aged 14-23 months who drink breast milk and formula milk. The study is conducted in Sekaran Village, Gunungpati Subdistrict, Semarang in April 2019. This study focuses on children aged 14-23 months who still drink breast milk and never drink milk from birth (drink infant formula). The growth variables observed are body weight and height. The population in this study are 115 children aged 12-24 months who weighed at Posyandu Sekaran Village, Gunungpati District, Semarang City. As for time constraints, the sample taken by the researcher amounted to 30 children who fit the inclusion criteria. The sample is divided into two groups, namely 15 children who are given breast milk and 15 children who are given formula milk in Sekaran Village, Gunungpati District, Semarang.

The sampling technique is purposive sampling, where the researcher takes samples in accordance with predetermined criteria. According to Sugiyono (2010), purposive sampling is a technique for determining samples with certain considerations so that the data obtained can be more representative. There are several criteria that are taken into consideration in determining the research sample. The criteria are in the form of inclusion criteria and exclusion criteria. Inclusion criteria are criteria that will be used as research samples. While exclusion criteria are criteria that are not sampled. Data collection techniques used by researchers are questionnaires, documentation, and interviews. The data analysis in this study is univariate and bivariate analysis. In this case, univariate analysis is used to analyze respondent data, weight growth variables and height. Bivariate analysis is used in analyzing the comparison of body weight and height growth of children aged 14-23 months who drink breast milk with children who drink formula milk. Inferential analysis used in the study is an independent $t$ test, because the hypothesis is in the form of a comparative hypothesis.

\section{RESULTS AND DISCUSSION}

The study is conducted in Sekaran Village in April 2019. The research sample consisted of 30 people, consisting of 15 children aged 14-23 months who drink breast milk and 15 children aged 14-23 months who drink infant formula. The study is conducted by distributing questionnaires, looking at KMS (health card), and interviewing respondents to determine the child's 
weight and height growth. The researcher conducts a preliminary interview to the parents who took the children to the Posyandu to get samples that matched the inclusion criteria. The researcher asks permission in advance to Sekaran Village to conduct research on children aged 14-23 months in Sekaran Village. After obtaining permission, the researcher participates in a series of activities throughout the Posyandu in Sekaran to get information related to the type of nutritional intake (breast milk and formula milk) and the age of the child. Furthermore, the researcher conducts a purposive sampling. Samples are selected according to predetermined inclusion criteria.

The researcher conducts door-to-door visitation to respondents who have children age 1423 months who are selected as a sample to obtain weight and height growth data through questionnaires and KMS (health card) documentation. Next, the researcher gives an informed consent sheet to the parents to ask for approval related to filling out the questionnaire and interview. If parents agree and are willing to become respondents, the researcher provides questionnaires about the identity of the respondents and the type of nutritional intake provided. The next step is interviews to get deeper information and complete the research data. The researcher records the baby's data contained in KMS (health card) and conducted documentation.

From the Table 1, it can be seen the average value of height growth of children who drink breast milk is $81.85 \mathrm{~cm}$ with a standard deviation of 3.39. The lowest height of the child who drinks milk is $78 \mathrm{~cm}$ and the highest body height is $87.20 \mathrm{~cm}$. While the average height growth of children who drink formula milk is $78.46 \mathrm{~cm}$ with a standard deviation of 4.91 . The lowest height for children who drink formula milk is $62 \mathrm{~cm}$ and the highest height is $84 \mathrm{~cm}$.

From the Table 2, it can be seen the average value of body weight growth of children who drink breast milk is $10.94 \mathrm{~kg}$ with a standard deviation of 0.35 . The lowest body weight of children who drink breast milk is $10.40 \mathrm{~kg}$ and the highest body weight is $11.80 \mathrm{~kg}$. While the average weight growth of children who drink formula milk is $11.83 \mathrm{~kg}$ with a standard deviation of 1.27 . The lowest body weight of children who drink formula milk is $9 \mathrm{~kg}$ and the highest body weight is $14 \mathrm{~kg}$.

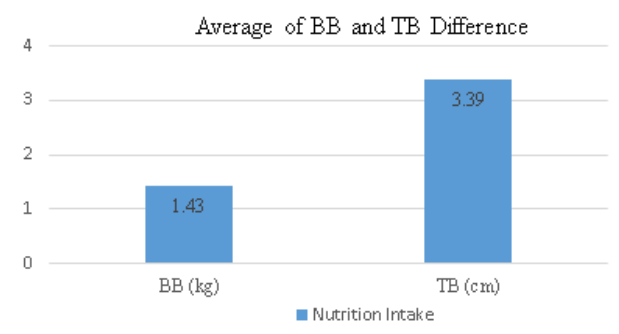

Figure 1. Graph of Weight and Height Difference Average of Children Age 14-23Months Based on Nutrition Intake (Breast Milk and Infant Formula)

From the Figure 1 results can be interpreted that the average value of body weight of children who drink breast milk and formula milk difference of $1.43 \mathrm{~kg}$ and the average value of height difference of $3.39 \mathrm{~cm}$. This difference is due to the pattern of giving complementary food to children. Respondents who give infant formula still give complementary food when the child is 6 months old. On average all respondents give complementary food when the child is 6 months old, both giving breast milk and formula milk. However, there are 3 respondents who give early complementary food for breast milk and 3 respondents who are late giving complementary food for breast milk (complementary food give over the age of 6 months). Food plays an important role in fulfilling energy and nutrition for children (Innayah et al, 2018).

Respondents provide nutritious complementary food for children, such as fruits and vegetables, and protein side dishes. Fruits that are usually given are watermelons, melons, oranges, apples, avocados, bananas, papayas, pears. The

Table 1. Distribution of Children's Age 14-23 Months Weight

\begin{tabular}{llcccc}
\hline & & Mean $(\mathrm{kg})$ & Std. deviation & Minimum & Maximum \\
\hline \multirow{2}{*}{ Nutrition Intake } & Breast milk & 10,94 & 0,35 & 10,40 & 11,80 \\
& Formula milk & 11,83 & 1,27 & 9 & 14 \\
\hline
\end{tabular}

Table 2. Distribution of Height Growth in Children Ages 14-23 Months

\begin{tabular}{llcccc}
\hline & & Mean $(\mathrm{cm})$ & Std. deviation & Minimum & Maximum \\
\hline \multirow{2}{*}{ Nutrition Intake } & Breast milk & 81,85 & 3,39 & 78 & 87,20 \\
& Formula milk & 78,46 & 4,91 & 62 & 84 \\
\hline
\end{tabular}


most popular vegetables for children are soup, spinach, broccoli, potatoes, cabbage, carrots, and mustard greens. Children are also given foods that contain high protein when they are 1 year old so that it can affect their growth rate. Examples of animal protein commonly given to children are eggs, salmon, gizzard, chicken. The results show that there are significant differences in body weight and height growth between children who drank milk and formula milk. Similar to the results of Ambarwati's research (2014) which showed that there were differences in growth in body weight, height, and head circumference in infants who were exclusively breastfed and those given PASI (complementary breast milk). The growth studied was body weight, height, and head circumference.

Children who drink breast milk have an ideal body weight according to age. The weight of a child who drinks breast milk increases according to his age every month. Whereas children who drink formula milk have less ideal body weight and some are overweight. This is because formula milk contains high glucose. Singal in Sasmiati (2017) said that the protein and mineral content of formula milk exceeds the nutritional adequacy rate of the baby, this makes the baby get excess food intake. The height of a child who drinks milk is included in the ideal category. Children who drink breast milk have an ideal height according to their age and weight, whereas, children who drink formula milk have a pretty ideal height.

Based on KMS (health card) results, the ideal body weight of children who drink breastmilk is 11 children $(73.33 \%$ ) while the ideal body weight of children who drink formula milk is 7 children $(46.66 \%)$. The number of ideal body weight of children who drink breast milk is more than children who drink infant formula milk. Growth of children who drink breast milk has normal average between body weight and height based the age. In contrast to children who drink formula milk that has more weight and quite ideal height.

The average body weight of a baby who is breastfed increases $0.5-1 \mathrm{~kg} /$ month in the first six months and height increases $1-2 \mathrm{~cm} /$ month. The growth of weight and height after six months slows. Furthermore, the addition of weight and height is only slightly. Whereas in the first six months, the average weight of infants who drink formula milk increases $1-2 \mathrm{~kg} /$ month and height increases $0.5-2 \mathrm{~cm} /$ month.

The growth of babies in the first six months experienced a growth spurt, but after the age of six months, the growth tends to slow down. In line with the opinion of Spyrides et al (2008) that after the age of six months, the weight of infants with exclusive breastfeeding is lower than babies who are not breastfed. It is strengthened by the opinion of Kuchenbecker et al (2015) that exclusive breastfeeding during the first six months is very important for babies to get optimal nutrition. There are many factors that affect a child's growth rate. These factors include genetic, complementary feeding, type of milk and quantity of milk given, as well as other factors. In this case, children who drink formula milk are overweight on average. One of the causes of a child being overweight is because of the glucose content in infant formula milk. Glucose can cause children to be overweight if consumed too much. This is supported by the opinion of Utami \& Wijayanti (2017) that the provision of formula milk with high energy and protein content early in life can increase the risk of obesity because energy intake exceeds the needs. The findings in the field, mothers give formula milk to their children in the amount of more than $1,000 \mathrm{ml} /$ day at the time of the baby. This causes the child to be overweight because the number of servings exceeds the needs of the baby. However, there are children who drink formula milk but are underweight. According to parents who have been interviewed by the researcher, underweight is caused because children drink little formula milk and have difficulty eating.

Children who drink breast milk have an ideal body weight. This is because breast milk contains adequate nutrition for babies. Children who get enough milk at birth will not experience growth retardation. The baby's body condition can adjust to breast milk, if it is full then the baby will immediately stop drinking milk and if hungry the baby will immediately look for the mother's nipples.

Child's weight and height growth is not only influenced by breast milk and formula milk. The type of complementary feeding after completing exclusive breastfeeding also affects the growth rate of the child. This is in accordance with the opinion of Uwaezuoke et al (2017) that the pattern of feeding infants to the age of two years is very influential on its growth. The growth of children who drink infant formula milk can be optimal if the child drinks milk according to the dosage recommended by health experts and pay attention to the consumed complementary food. Infant formula milk contains protein that is needed in the growth process of children. Based on the results of interviews with respondents, they made no effort to increase children's height, res- 
pondents allowed children to grow naturally (not providing any supplements). The respondents believe that formula contains ingredients that can increase children's growth.

It can be concluded that the growth of children who drink breast milk and formula milk has a different average. There are differences in body weight and height between children who drink breast milk and children who drink formula milk. Children who drink breast milk have ideal body weight and height. The growth rate of children who drink breast milk is normal according to their age, whereas, children who drink infant formula milk have less ideal weight and ideal height. The growth rate of children who drink formula milk is included in the less category.

\section{CONCLUSION}

From the results of the analysis and discussion above, it can be concluded that: (a) there is a difference in body weight growth between children aged 14-23 months who drink breast milk and children aged 14-23 months who drink formula milk, (b) there are differences in height growth between children aged 14-23 months who drink breast milk with children aged 14-23 months who drink formula milk.

\section{REFERENCES}

Ambarwati, W. (2014). Perbandingan Pertumbuhan Bayi yang Diberi Air Susu Ibu (ASI) Eksklusif dengan Pengganti Air Susu Ibu (PASI) di Kelurahan Kebon Jeruk Jakarta. Skripsi. Jakarta: UIN Syarif Hidayatullah.

Conita, A. D. (2014). Perbedaan Pertumbuhan Bayi Usia 3-6 Bulan yang Diberi ASI Eksklusif dan yang Tidak Diberi ASI Eksklusif di Puskesmas Gang Sehat Kecamatan Pontianak Selatan. Skripsi. Pontianak: Program Studi Pendidikan Dokter Universitas Tanjungpura Pontianak.

Dahliansyah, H. D., \& Salimo, H. (2018). Hubungan Pemberian ASI Eksklusif, Status Gizi, dan Kejadian Diare dengan Perkembangan Motorik pada 1000 Hari Pertama Kehidupan. Sari Pediatri, 20(2), 70-80.

Danang, W. (2015). Hubungan Pengetahuan Ibu, Pekerjaan Ibu, dan Promosi Susu Formula dengan Kegagalan Pemberian ASI Eksklusif pada Balita Usia 0-6 bulan di Wilayah Kerja Puskesmas Bojong. Skripsi. Purwokerto: Program Studi Ilmu Keperawatan Universitas Muhammadiyah Purwokerto.

Estuti, D. H. (2014). Partisipasi Masyarakat Dalam Layanan Posyandu Terhadap Pertumbuhan
Balita (di Desa Mergowati Kecamatan Kedu Kabupaten Temanggung). Journal of Early Chilhood Education Papers, 3(2), 1-8

Febriana, L. L. R., \& Pranoto, Y. K. S. (2018). The Study of Sasak Baby Care in Sade Village Central Lombok. Journal of Early Chilhood Education Papers, 7(2), 76-81.

Himawan, A. W. (2006). Hubungan Antara Karakteristik Ibu dengan Status Gizi Balita di Kelurahan Sekaran Kecamatan Gunungpati Semarang. KEMAS Journal, 1(2), 6-9

Innayah, D. S., \& Mukminin, A. (2018). Parents' Understanding of Additive Synthetic Through Healthy Lunch-Box Parenting Practice. Indonesian Journal of Early Childhood Education Studies, $7(2)$.

Kuchenbecker. (2015). Exclusive breastfeeding and its effect on growth of Malawian infants: results from a cross-sectional study. Pediatrics and International Child Health, 35(1), 14-23.

Notoatmodjo, S. (2005). Metodologi Penelitian Kesehatan. Jakarta: Rineka Cipta.

Nursalam. (2003). Konsep \& Penerapan Metodologi Penelitian Ilmu Keperawatan: Pedoman Skripsi, Tesis dan Instrumen Penelitian. Jakarta: Salemba Medika.

Putri, V. D. (2012). Praktik Pengasuhan Anak Pada Keluarga Petani Peserta Bina Keluarga Balita (BKB) Melati 3 di Desa Nguken Kecamatan Padangan Kabupaten Bojonegoro. Journal of Early Chilhood Education Papers, 1(1), 6-11.

Rarastiti, C. N., \& Syauqy, A. (2013). Hubungan Karakteristik Ibu, Frekuensi Kehadiran Anak Ke Posyandu, Asupan Energi Dan Protein Dengan Status Gizi Anak Usia 1-2 Tahun. Journal of Nutrition College, 3(1), 98-105

Sara, H. (2018). Tumbuh Kembang Bayi yang Mendapatkan ASI Eksklusif di Wilayah Kerja Puskesmas Simpang Baru Kota Pekanbaru. Jurnal Kebidanan, 7(2), 166-176.

Sasmiati. (2017). Hubungan Konsumsi Susu Formula dengan Status Gizi Balita di Puskesmas Piyungan Bantul Yogyakarta. Yogyakarta: Universits 'Aisyiyah Yogyakarta.

Spyrides, M. H. C. (2008). Effect of predominant breastfeeding duration on infant growth: a prospective study using nonlinear mixed effect models. Journal de Pediatria, 84(3), 237-243.

Sugiyono. (2010). Metode Penelitian Pendidikan (Pendekatan Kuantitatif, Kualitatif, dan R\&D). Bandung: Alfabeta.

Utami, C., \& Wijayanti, H. (2017). Konsumsi susu formula sebagai faktor risiko kegemukan pada balita di Kota Semarang. Journal of Nutrition College, 6(1), 96-102

Uwaezuoke, S. N., Eneh, C. I., \& Ndu, I. K. (2017). Relationship between exclusive breastfeeding and lower risk of childhood obesity: a narrative review of published evidence. Clinical Medicine Insights: Pediatrics, 11, 1179556517690196. 